\title{
Suppression of activin A signals inhibits growth of malignant pleural mesothelioma cells
}

\author{
MA Hoda',2,7, J Münzker 2,7, B Ghanim', K Schelch², T Klikovits', V Laszlo', E Sahin², A Bedeir², \\ A Lackner ${ }^{2}$, B Dome ${ }^{1,3}$, U Setinek ${ }^{4}$, M Filipits ${ }^{2}$, M Eisenbauer ${ }^{2}$, I Kenessey ${ }^{5}$, S Török ${ }^{3}$, T Garay ${ }^{5}$, B Hegedus ${ }^{1,2,5}$, \\ A Catania', 5 Taghavi', W Klepetko', W Berger ${ }^{2}$ and M Grusch ${ }^{2}$ \\ 'Division of Thoracic Surgery, Department of Surgery, Comprehensive Cancer Center, Medical University of Vienna, Vienna, Austria; ${ }^{2}$ Department of \\ Medicine I, Institute of Cancer Research, Comprehensive Cancer Center, Medical University of Vienna, Borschkegasse 8a, Vienna I090, Austria; ${ }^{3}$ National \\ Koranyi Institute of TB and Pulmonology, Budapest, Hungary; ${ }^{4}$ Division of Pathology, Otto Wagner Hospital, Vienna, Austria; ${ }^{5}$ Second Department of \\ Pathology, Semmelweis University, Budapest, Hungary; ${ }^{6}$ Ospedale Policlinico, Via F. Sforza 35, Milano, Italy
}

BACKGROUND: Activins control the growth of several tumour types including thoracic malignancies. In the present study, we investigated their expression and function in malignant pleural mesothelioma (MPM).

METHODS: The expression of activins and activin receptors was analysed by quantitative PCR in a panel of MPM cell lines. Activin A expression was further analysed by immunohistochemistry in MPM tissue specimens $(N=53)$. Subsequently, MPM cells were treated with activin $A$, activin receptor inhibitors or activin-targeting siRNA and the impact on cell viability, proliferation, migration and signalling was assessed.

RESULTS: Concomitant expression of activin subunits and receptors was found in all cell lines, and activin A was overexpressed in most cell lines compared with non-malignant mesothelial cells. Similarly, immunohistochemistry demonstrated intense staining of tumour cells for activin $A$ in a subset of patients. Treatment with activin A induced SMAD2 phosphorylation and stimulated clonogenic growth of mesothelioma cells. In contrast, treatment with kinase inhibitors of activin receptors (SB-43 I 542, A-830 I) inhibited MPM cell viability, clonogenicity and migration. Silencing of activin A expression by siRNA oligonucleotides further confirmed these results and led to reduced cyclin DI/3 expression.

CONCLUSION: Our study suggests that activin A contributes to the malignant phenotype of MPM cells via regulation of cyclin D and may represent a valuable candidate for therapeutic interference.

British Journal of Cancer (2012) I 07, 1978-1986. doi:I0.1038/bjc.2012.5 I9 www.bjcancer.com

Published online 20 November 2012

(C) 2012 Cancer Research UK

Keywords: mesothelioma; activin; activin receptor; SMAD signalling; targeted therapy

Malignant pleural mesothelioma (MPM) is a highly lethal malignancy strongly associated with asbestos exposure (Peto et al, 1999). Owing to the long latency period of 20-40 years, the incidence of MPM is expected to increase dramatically over the next few decades despite the implementation of a ban on asbestos use in most countries since the 1980s. Estimations predict 250000 people to die from MPM in Europe in the next 30 years and 2500-3000 new cases to be diagnosed each year in the United States (Peto et al, 1999; Robinson and Lake, 2005). The expected median survival of patients suffering from MPM is still poor ranging from 4 to 12 months after diagnosis (Zucali and Giaccone, 2006). Aggressive cytoreductive therapy, including surgery (extrapleural pneumonectomy) in combination with chemotherapy and radiation (trimodality therapy), has been shown to prolong survival in selected patients with early MPM (Sugarbaker et al, 1996). However, even the most successful current chemotherapy regimen (pemetrexed/cisplatin) prolongs median

\footnotetext{
* Correspondence: Dr M Grusch;

E-mail: michael.grusch@meduniwien.ac.at

${ }^{7}$ These authors contributed equally to this work.

Received 25 May 2012; revised 24 October 2012; accepted 26 October 2012; published online 20 November 2012
}

survival only by a few months (Vogelzang et al, 2003). Therefore, a better understanding of the mechanisms controlling malignant growth of MPM cells and the rational development of new therapeutic concepts with higher efficiency and defined cellular targets remains an important priority (Jackman, 2009).

Activins are members of the transforming growth factor $\beta$-(TGF- $\beta$ ) superfamily of growth and differentiation factors. Activin $\mathrm{A}$, a homodimer of two $\beta \mathrm{A}$ subunits, has important physiological roles in cell differentiation, wound healing and inflammation (Werner and Alzheimer, 2006) and has the ability to either inhibit or promote growth, depending on the cell type. With respect to cancer, activin A was shown to inhibit cell proliferation in hepatocellular carcinoma (Chen et al, 2000), breast cancer (Burdette et al, 2005) or prostate cancer (Wang et al, 1996). Accordingly, tumours from these organs often show overexpression of activin antagonising proteins such as follistatin (Grusch et $a l, 2006$ ) or FLRG (Razanajaona et al, 2007). In contrast, promotion of cell proliferation by activin A was demonstrated in endometrial carcinoma (Tanaka et al, 2004), oral squamous cell carcinoma (Chang et al, 2010) and several thoracic tumours, such as oesophageal squamous cell carcinoma (Yoshinaga et al, 2008), oesophageal adenocarcinoma (Seder et al, 2009a) and lung adenocarcinoma (Seder et al, 2009b). In these cancer types, 
overexpression of activin A was found and often associated with poor prognosis, enhanced metastasis or a shorter disease-free survival time (Yoshinaga et al, 2003; Seder et al, 2009b; Chang et al, 2010). Moreover, downregulation of activin A gene expression via RNA interference reduced cell proliferation and invasion of cancer cells from these malignancies (Seder et al, 2009a,b; Chang et al, 2010), thus demonstrating the importance of activin A signalling for various carcinomas and suggesting activin $\mathrm{A}$ as a potential candidate for therapeutic interference.

In the present study, we show that activin A is highly expressed in MPM cell lines and in a subset of MPM tissue specimens. Furthermore, we demonstrate that inhibition of activin receptors or silencing of activin A gene expression impairs growth and migration of MPM cells.

\section{MATERIALS AND METHODS}

\section{Cell culture}

SPC111, SPC212 and M38K cells were established from biphasic MPM and kindly provided by Professor R Stahel (SPC11 and SPC212, University of Zurich, Zurich, Switzerland) and Professor VL Kinnula (M38K, University of Helsinki, Helsinki, Finland). All other mesothelioma cell lines were from epitheloid MPM. The I2 MPM cell line was kindly provided by Professor A Catania (University of Milano, Milano, Italy). The CRL5820 and the nontransformed mesothelial cell line Met5a were purchased from the American Type Culture Collection (Manassas, VA, USA). P31 and their cisplatin-resistant derivative P31res1.2 (established by in vitro cisplatin selection) were kindly provided by Professor $\mathrm{K}$ Grankvist (University of Umea, Umea, Sweden). The VMC6 and VMC20 cell lines were established by our group following published protocols (Sagmeister et al, 2008). The MPM cell lines were maintained in RPMI1640 or MEM with $10 \%$ fetal calf serum (PAA, Pasching, Austria). Cell lines were authenticated by arraycomparative genomic hybridisation or DNA fingerprinting and regularly checked for Mycoplasma contamination.

\section{RNA isolation, cDNA synthesis and real-time PCR}

Isolation of total RNA from logarithmically growing cells was performed with TRIzol (Life Technologies, Carlsbad, CA, USA) and $2 \mu \mathrm{g}$ RNA per sample were reverse transcribed with MMLV reverse transcriptase (Thermo Scientific, Waltham, MA, USA). One microlitre cDNA, corresponding to $50 \mathrm{ng}$ RNA, was analysed per PCR. Quantitative real-time PCR (QPCR) was performed with Taqman assays or SYBR Green (Life Technologies), as previously described (Grusch et al, 2006), on an ABI Prism 7500 thermocycler (Life Technologies). Assay IDs, primer sequences and annealing temperatures are listed in Supplementary Tables S1 and S2. The housekeeping genes $\beta$-2 microglobulin, glyceraldehyde-3 phosphate dehydrogenase (GAPDH), $\beta$-actin and 18 s ribosomal RNA were used for normalisation, and semiquantitative determination of gene expression was performed by applying the $2^{(-\Delta \Delta \mathrm{CT})}$ method using Met5a as calibrator. All expression analyses were performed in duplicates and repeated at least twice.

\section{Tissue samples}

Formalin-fixed, paraffin-embedded tumour tissue was available from 53 MPM patients resected between 1993 and 2010 at the Medical University of Vienna, Department of Surgery. All procedures were approved by the local Ethics Committee. Tissues were embedded during routine diagnostic work-up and coded by the Department of Pathology. Sections from each tumour block were cut at $4 \mu \mathrm{m}$. Haematoxylin and eosin staining was used to confirm the presence of invasive cancer.

\section{Immunohistochemistry}

Briefly, tissue sections were deparaffinised and rehydrated. After epitope retrieval, sections were incubated overnight at $4{ }^{\circ} \mathrm{C}$ with primary antibodies (anti activin A, AbD Serotec, Kidlington, UK; Ki67, Dako, Glostrup, Denmark; dilutions 1:100). Specificity of the activin A antibody was confirmed by immunoblotting using recombinant human (rh) activin A. Bound antibody on tissue sections was detected with the UltraVision LP detection system (Thermo Scientific). Colour development was done by $3,3^{\prime}$ diaminobenzidine and counterstaining by haematoxylin. Staining was evaluated by a thoracic pathologist unaware of the patients' clinicopathological status. Only cytoplasmic staining of activin A was considered positive. Mean staining intensity was scored as absent (0), weak (1), moderate (2) or strong (3). The results were correlated with clinical/histological data using SPSS 17 software (SPSS Inc., Chicago, IL, USA).

\section{Western blot analysis}

Cells were seeded into six-well plates at a density of $3 \times 10^{5}$ per well. After $24 \mathrm{~h}$, cells were incubated with rh activin A ( $20 \mathrm{ng} \mathrm{ml}^{-1}, \mathrm{R} \& \mathrm{D}$ Systems, Minneapolis, MN, USA) for $30 \mathrm{~min}$ or transfected with siRNA oligonucleotides for $24 \mathrm{~h}$ as described below. Then proteins were extracted and processed for SDS-PAGE and immunoblotting as published (Hoda et al, 2011). The following primary antibodies were used: rabbit polyclonal to pSMAD2 (\#3101), total SMAD2/3 (\#3102), pERK1/2 (\#9101), total ERK1/2 (\#9102), mouse monoclonal to cyclin D1 (\#2926), D2 (\#2924) and D3 (\#2936), rabbit monoclonal to $\beta$-tubulin (\#2128) (all from Cell Signaling Technology, Danvers, MA, USA), mouse monoclonal to $\beta$-actin (Sigma, St Louis, MO, USA) at 1:1000 dilutions in PBS with $3 \%$ BSA. Horseradish peroxidase-coupled anti-rabbit/mouse antibodies (3\% BSA, Dako) were used at $1: 10000$ dilutions and blots developed with Western C reagent (Bio-Rad, Hercules, CA, USA). Bio-1D software (Vilber Lourmat, Eberhardzell, Germany) was used for band quantification.

\section{Clonogenic assay}

One thousand cells per well were seeded into six-well plates. After $24 \mathrm{~h}$, the medium was removed, cells were washed once with PBS and treated with $20 \mathrm{ng} \mathrm{ml}^{-1} \mathrm{rh}$ activin A (in PBS $0.1 \%$ BSA) or $2.5-20 \mu \mathrm{M}$ of the activin receptor inhibitors SB-431542 or A-8301 (both from Tocris Bioscience, Bristol, UK) in DMSO. Controls were treated with solvent only. Treatment medium was renewed every $72 \mathrm{~h}$. After 10-14 days, the medium was removed and colonies were stained with crystal violet. For photometric quantification, colonies were destained with $2 \%$ SDS and absorbance was measured at $562 \mathrm{~nm}$ using a SynergyHT plate reader and Gen5 software (BioTek, Winooski, VT, USA).

\section{Scratch assay}

Scratches were applied to confluent cultures in six-well plates using a pipette tip, medium was renewed and the indicated treatments were added. Scratches were photographed after $0,4,8,24$ and $48 \mathrm{~h}$, and wound closure was calculated from the micrographs with Image $J$ software (National Institutes of Health, Bethesda, MD, USA).

\section{Cell viability assay}

Cells were seeded in triplicates into 96 -well plates at a density of $2 \times 10^{3}$ cells per well. The next day, medium was replaced with $100 \mu \mathrm{l}$ fresh medium containing the indicated treatments and cells were incubated for $72 \mathrm{~h}$. Cell viability was determined with the EZ4U kit (Biomedica, Vienna, Austria) following the manufacturer's instructions. Absorbance was measured at 450 and $620 \mathrm{~nm}$ (as reference) as described above. Experiments were repeated at least three times. 

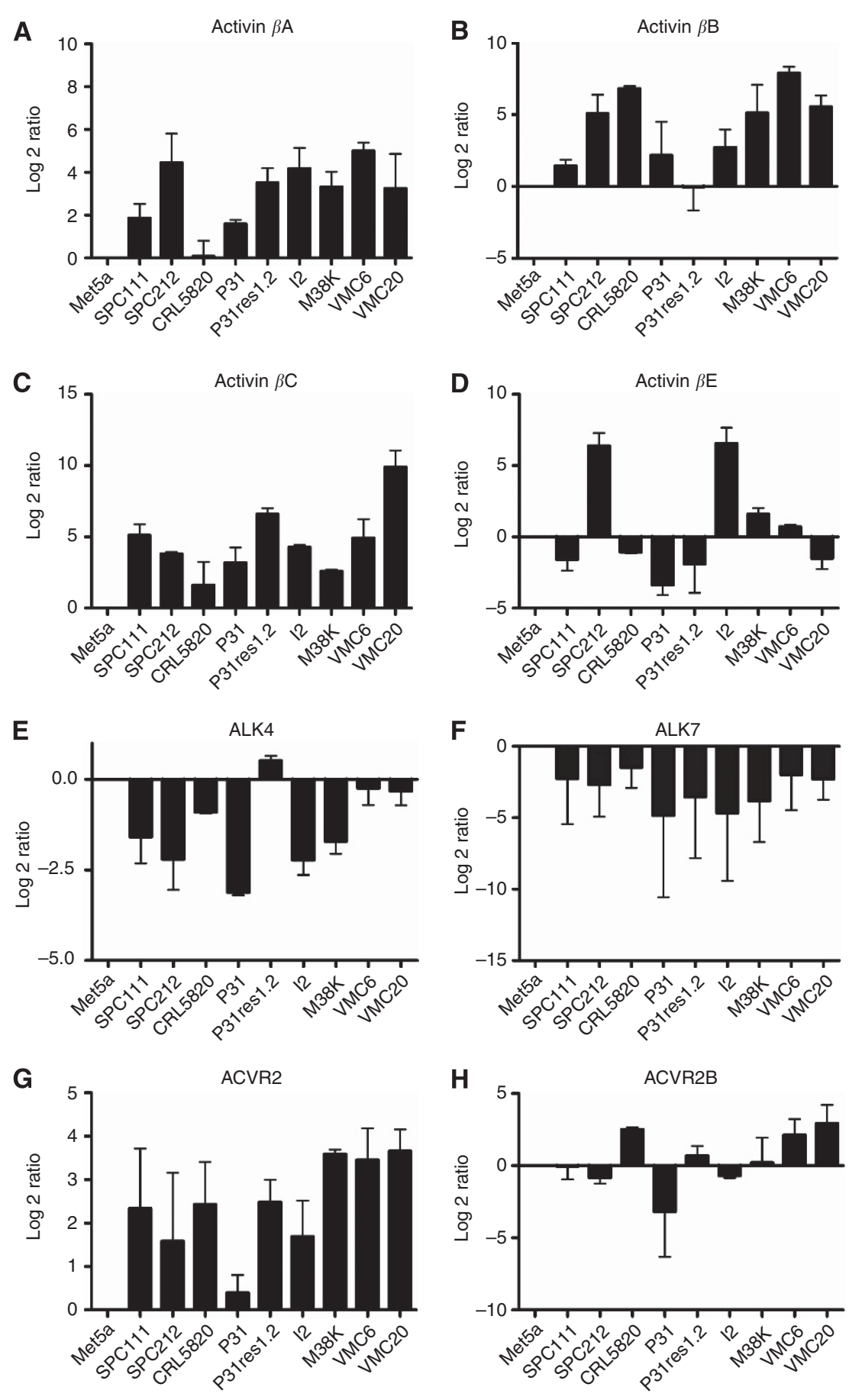

Figure I Expression of activin family genes in MPM cell models. RNA was extracted and reverse transcribed from subconfluent cultures of MPM cells and the non-malignant mesothelial cell line Met5a. The expression levels were determined with Taqman assays (activin subunits, A-D) or SYBR green real-time PCR (activin receptors, E-H) by the $2^{(-\Delta \Delta C T)}$ method using GAPDH for normalisation and Met5a as calibrator. Log 2 ratios of fold change compared with Met5a from at least two independent experiments performed in duplicates are shown.

\section{Gene silencing}

Cells were seeded into six-well plates at a density of $2 \times 10^{5}$ per well in full growth medium. The next day, cells were transfected with $50 \mathrm{nM}$ siRNA targeting activin $\beta \mathrm{A}$ or non-silencing siRNA (both from Dharmacon, Lafayette, CO, USA) and Oligofectamine (Life Technologies) as transfection reagent. Cells were collected $48 \mathrm{~h}$ after transfection for determination of silencing efficiency by Taqman assays. Cell viability, colony formation and protein expression were tested as described above, except that clonogenic assays were performed in 12-well instead of 6-well plates.

\section{Statistical analysis}

Data are expressed as means \pm s.d. from at least three individual experiments, except for staining scores, which are shown as box blots. Statistical significance of differences was determined by 
A
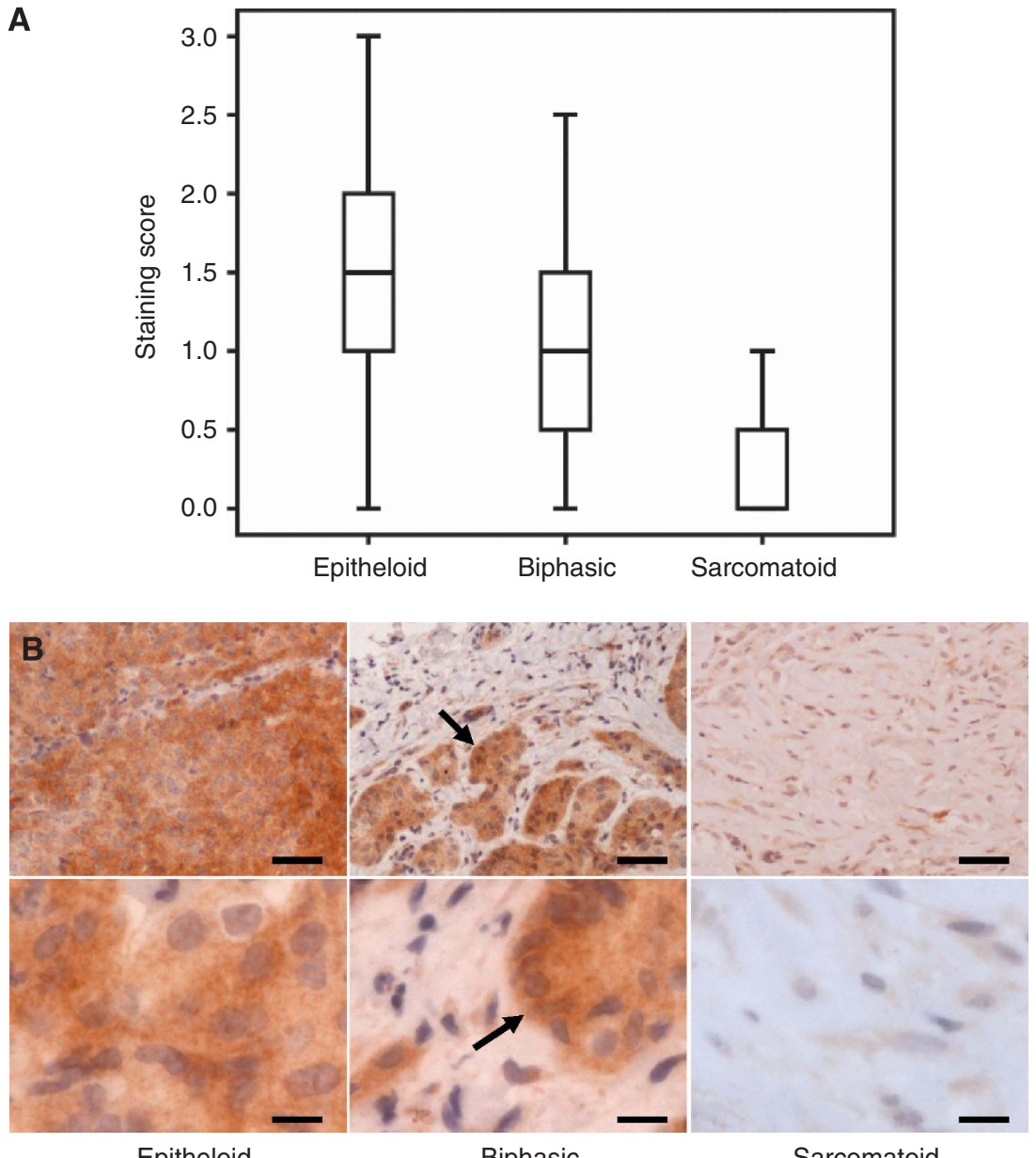

Figure 2 The expression of activin A in MPM tissue. Fifty-three human paraffin-embedded MPM surgical specimens of different histology were immunostained for activin A (brown) and nuclei were counterstained with haematoxylin (blue). (A) Staining intensities were scored as described in Materials and Methods and box plots of staining scores for the different histological subtypes are shown. (B) Representative examples of activin A-stained specimens of epitheloid, biphasic and sarcomatoid MPM at low (upper panels, scale bar $=40 \mu \mathrm{m}$ ) and high (lower panels, scale bar $=10 \mu \mathrm{m}$ ) magnification. Note that intense staining in biphasic MPM is restricted to the epitheloid compartment (arrows).

using unpaired $t$-test, $\chi^{2}$-test or one-way or two-way ANOVA, as appropriate. $P$-values $<0.05$ were considered statistically significant. Survival analysis was performed using Kaplan-Meier curves, log-rank test and the Cox-regression model.

\section{RESULTS}

\section{Malignant pleural mesothelioma cell lines (over)express activin family members}

The transcript levels of the activin subunits $(\beta \mathrm{A}, \beta \mathrm{B}, \beta \mathrm{C}$ and $\beta \mathrm{E}$, Figure $1 \mathrm{~A}-\mathrm{D})$ as well as the activin type I and type II receptors (ALK4, ALK7, ACVR2, ACVR2B, Figure 1E-H) were analysed using QPCR. Analyses were performed in nine MPM cell lines in comparison with the non-malignant mesothelial cell line Met5a. All cell lines expressed detectable levels of activin subunits as well as activin receptors. Importantly, the activin $\beta \mathrm{A}$ subunit, which has been previously linked to tumour aggressiveness in thoracic malignancies (Yoshinaga et al, 2008; Seder et al, 2009b), was elevated more than four-fold ( $\log 2$ ratio $>2$ ) in six of nine MPM cell lines. Among the activin receptors, the type I receptors were mostly downregulated, whereas the type II receptor ACVR2 was upregulated. Activin signals are kept in balance by several antagonists such as follistatin, fstl3/FLRG, inhibin- $\alpha$ and TDGF1/ cripto-1. However, none of these showed a clear trend of up- or downregulation in MPM cell lines (Supplementary Figure S1). No significant correlation was found between the expression level of the $\beta \mathrm{A}$ subunit and activin receptors or activin antagonists.

\section{Activin A is highly expressed in epitheloid MPM tissue}

As activin $\beta \mathrm{A}$ was overexpressed in the majority of MPM cell lines, we next tested, whether activin $\mathrm{A}$ is also present in tissue specimens from MPM patients. Paraffin-embedded tissue samples were available from 36 patients with epitheloid, 13 with biphasic and 4 with sarcomatoid MPM. Activin A staining of tumour cells is displayed as mean staining score for the three different histological subtypes (Figure 2A). Overall, 6 (11.3\%), 20 (37.7\%), 20 (37.7\%) and $7(13.2 \%)$ of the tumours had strong, moderate, weak or absent staining, respectively. Representative cases are shown in Figure 2B. There was a significant association of activin A expression with epitheloid $v s$ non-epitheloid histology $(P=0.005)$, but not with patient survival, stage or nuclear Ki67 expression. In tumours with biphasic histology, activin A was predominantly present in the epithelial compartment.

\section{Activin A stimulates growth and migration of MPM cells}

Activin A has been connected to either apoptosis induction or more aggressive growth of tumour cells depending on the cell type. 

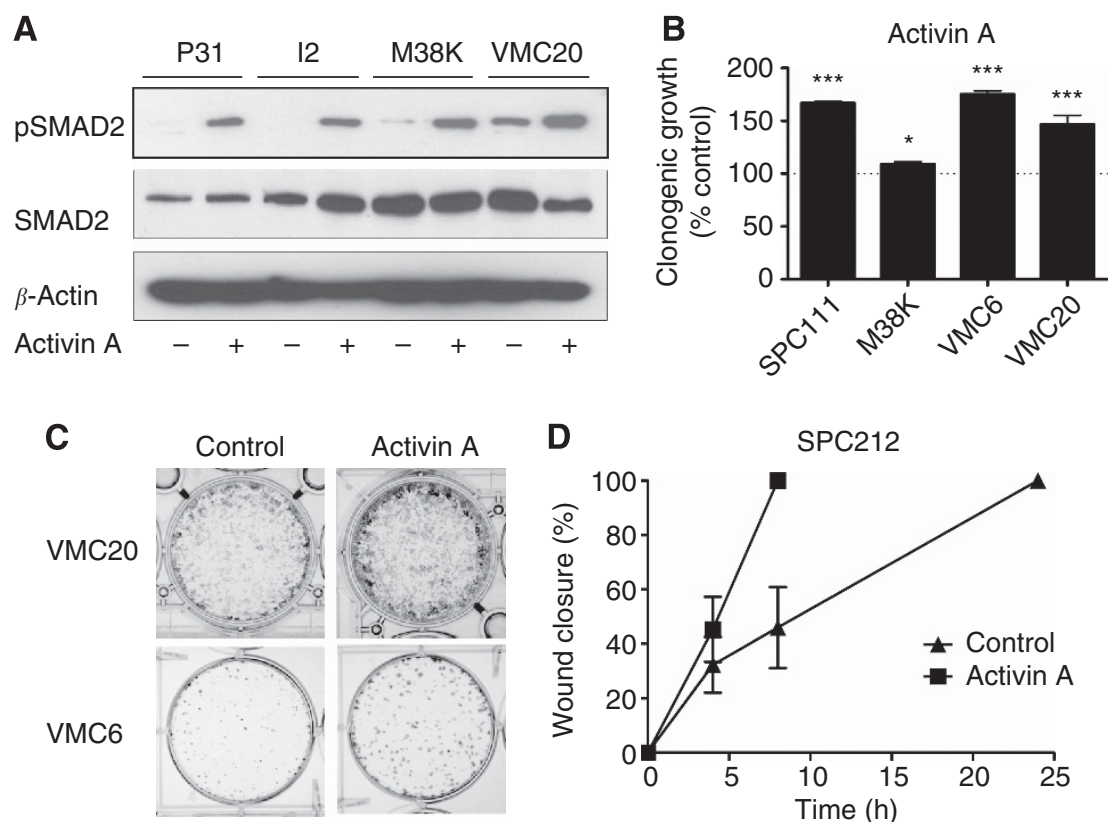

Figure 3 Activin A induces SMAD phosphorylation and supports migration and clonogenic growth. (A) A total of $5 \times 10^{5}$ cells were seeded into each well of six-well plates and after $24 \mathrm{~h}$ treated with $20 \mathrm{ng} \mathrm{ml}^{-1}$ activin A for $30 \mathrm{~min}$. Cells were collected and assayed for phospho- and total SMAD2 as well as $\beta$-actin as loading control. (B, C) A total of $10^{3}$ cells were seeded into six-well plates and treated with $20 \mathrm{ng} \mathrm{ml}^{-1}$ activin A for 10 days. Wells were stained with crystal violet, destained in 2\% SDS and absorption at $562 \mathrm{~nm}$ was determined. Data from at least two duplicate determinations (B) and representative examples $(\mathbf{C})$ are shown. (D) Cells were grown to near confluence in six-well plates and a scratch wound was applied with a pipette tip. After a medium change, cells were treated with $20 \mathrm{ng} \mathrm{ml}^{-9}$ activin A and wound closure was determined microscopically after 4,8 and $24 \mathrm{~h}$. *P<0.05, **** $P<0.00 \mathrm{l}$.

Therefore, we next evaluated the response of MPM cells to activin A. First, we tested induction of SMAD signalling by activin A. When MPM cell lines were treated with recombinant activin A, an increase of phosphorylated SMAD2 was seen in all tested cell lines (Figure 3A). VMC20 and M38K also showed a considerable degree of SMAD2 activation in the absence of activin A treatment. No activation of MAP-kinase signalling (p38, ERK1/2) by activin A was seen in any of the cell lines (data not shown). When clonogenic growth/survival assays were performed, activin A induced a stimulation of up to $50 \%$ compared with mock-treated controls (Figure 3B and C). Also cell migration, analysed by scratch assay, was enhanced (Figure 3D). This demonstrates that activin A signal transduction via the canonical SMAD pathway is active in MPM cells and that MPM cells respond to activin A with increased growth and migration.

\section{Inhibition of activin receptors impairs growth, clonogenicity and migration of MPM cells}

As activin A supported MPM cell growth and MPM cell lines expressed activin $\beta \mathrm{A}$, we next tested the dependency of MPM cell lines on activin receptor signals. Two different kinase inhibitors (SB-431542 and A-8301) targeting type I activin receptors (activinlike receptor kinases, ALK) were used. SB-431542 induced a dosedependent inhibition of clonogenicity (Figure 4A). A similar growth inhibitory effect was also seen with A-8301, or when colorimetric short-term viability assays were performed instead of the clonogenic assays with SB-431542 (Figure 4B and C). Wound closure in scratch assays was also significantly delayed by SB431542 (Figure 4D).

\section{Silencing of activin $\beta \mathrm{A}$ reduces viability and clonogenicity of MPM cells}

As an additional proof for dependency of MPM cells on activin A, we silenced activin $\beta$ A expression by siRNA. As shown in
Figure 5A, a knockdown efficiency of around 75\% was achieved when compared with respective mock controls (non-silencing siRNA). Again, a decrease of viability of $30-50 \%$ was seen in all cell models tested, except for $\mathrm{P} 31$, which showed no response in the short-term assay (Figure 5B). However, both P31 and its cisplatinresistant derivative were inhibited in the clonogenic assay (Figure 5C).

To gain deeper insight into potential mechanisms underlying these effects, we analysed cyclin D expression and ERK1/2 phosphorylation of MPM cells in response to activin A silencing (Figure 6). Although cyclin D2 was not expressed at detectable levels, repression of cyclin D1 and cyclin D3 was observed in VMC20 cells and to a more moderate degree also in P31. Reduced ERK1/2 phosphorylation was only seen in the VMC20 cell line, whereas P31 showed a slight increase.

\section{DISCUSSION}

Despite considerable efforts to improve the outcome of patients suffering from MPM (Kelly et al, 2011), the prognosis remains still poor. This emphasises the urgent need for a better understanding of the molecular changes leading to the development of MPM, which could serve as basis for designing new molecularly targeted treatment strategies.

Activins represent possible interventional targets, as they are involved in the control of cell proliferation and differentiation, and are frequently deregulated in a variety of malignancies (Risbridger et al, 2001; Tsuchida et al, 2009). In liver cancer, for instance, tumour cells displayed decreased expression levels of activin A compared with normal hepatocytes (Vejda et al, 2003) and there is evidence for a decrease in activin signals in other cancer types such as breast and colorectal carcinoma (Jeruss et al, 2003; Jung et al, 2004). Interestingly, in tumour cells from these malignancies, treatment with activin A exerted growth-suppressive effects (Vejda et al, 2003; Burdette et al, 2005; Razanajaona et al, 2007) that we 
A
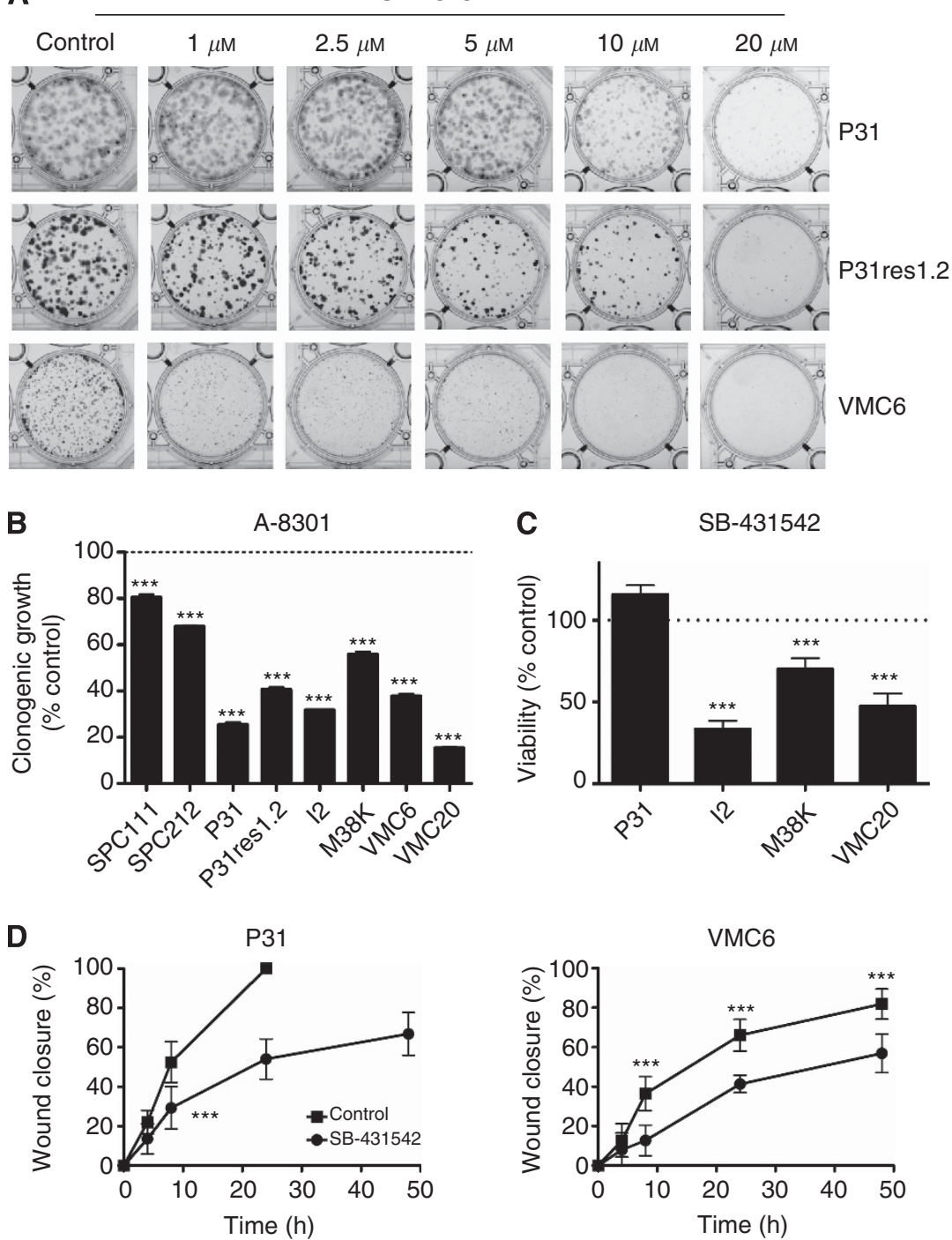

Figure 4 Activin receptor inhibition impairs MPM cell growth and migration. (A) The MPM cells ( $10^{3}$ per well) were seeded into six-well plates and after $24 \mathrm{~h}$ treated with the indicated concentrations of SB-43I542 or solvent (DMSO) as control for 10 days. Plates were stained with crystal violet and photographed. (B) Cells were seeded as in A and treated with $20 \mu \mathrm{M} \mathrm{A-830} \mathrm{I.} \mathrm{Plates} \mathrm{were} \mathrm{destained} \mathrm{with} \mathrm{2 \%} \mathrm{SDS} \mathrm{and} \mathrm{absorption} \mathrm{was} \mathrm{measured} \mathrm{at} 562 \mathrm{~nm}$. (C) A total of $2 \times 10^{3}$ cells per well were seeded into 96-well plates and treated the next day with $20 \mu \mathrm{M}$ SB- 43 I 542 for $72 \mathrm{~h}$. Cell viability was determined by MTT assay. (D) Cells were grown to near confluence in six-well plates and treated with SB-43I542 or solvent after application of a scratch wound with a pipette tip. Wound closure was measured after 4, 8, 24 and $48 \mathrm{~h}$. $* * * *<0.001$

recapitulated in the HepG2 hepatoma cells in this study (Supplementary Figure S2). In contrast, a pro-tumourigenic role of activin A via the tumour microenvironment has recently been demonstrated in a mouse model of skin tumourigenesis (Antsiferova et al, 2011). Similarly, increased activin A levels were found in thoracic malignancies, and treatment with activin A or ectopic overexpression of activin $\beta \mathrm{A}$ was associated with enhanced tumour cell aggressiveness (Yoshinaga et al, 2008; Seder et al, 2009a,b).

In MPM, previous studies demonstrated an inhibition of cell proliferation and tumour growth by antisense RNA to TGF- $\beta$ (Fitzpatrick et al, 1994) - a cytokine of the same superfamily-but the role of activin signals in MPM has not been investigated so far. In the current study, we found increased expression of the activin subunits $\beta \mathrm{A}, \beta \mathrm{B}$ and $\beta \mathrm{C}$ on the transcript level by QPCR in a panel of MPM cell lines, whereas in contrast to liver tumours (Grusch et al, 2006), melanoma (Stove et al, 2004) or breast cancer (Razanajaona et al, 2007), no consistent upregulation of the activin antagonists follistatin or FLRG was observed. Elevated expression of activin $\mathrm{B}$ or $\mathrm{C}$ has been reported in other malignancies as well (Gold et al, 2009; Frost et al, 2011), but their function in tumour biology remains largely uncharacterised. As activin $\mathrm{A}$ has previously been implicated in malignant progression, we focused the subsequent analysis on this member of the activin family. Elevated activin A expression was confirmed by immunohistochemistry in tissue sections. This is in line with several recent publications, for instance in lung cancer (Seder et al, 2009b) oesophageal adenocarcinoma (Seder et al, 2009a) oral squamous cell carcinoma (Chang et al, 2010) and gastric cancer (Wang et al, 2010). Our results indicate that MPM is also characterised by increased rather than decreased activin A levels. However, in contrast to oral squamous cell carcinoma (Chang et al, 2010), stage I lung adenocarcinoma (Seder et al, 2009b) and gastric cancer in a Chinese population (Wang et al, 2010), expression was not associated with a worsened disease outcome. This could be explained by the rather heterogeneous patient collective as a result of different treatment approaches currently applied in MPM. Similar to phospho-mTOR (Hoda et al, 2011), activin A was 

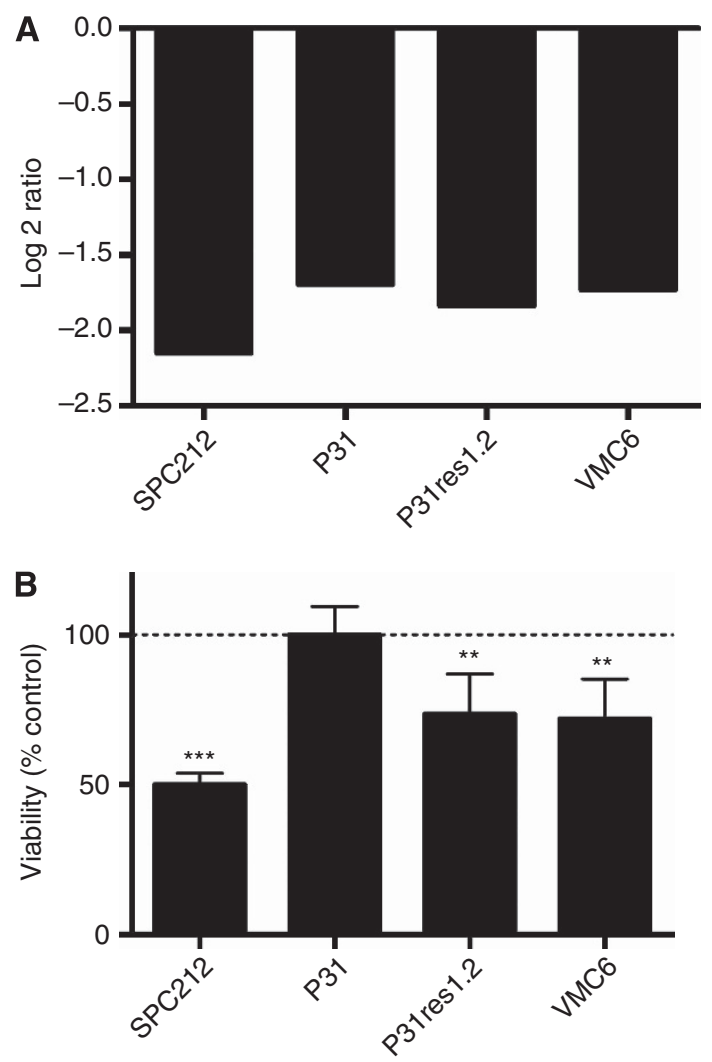

C

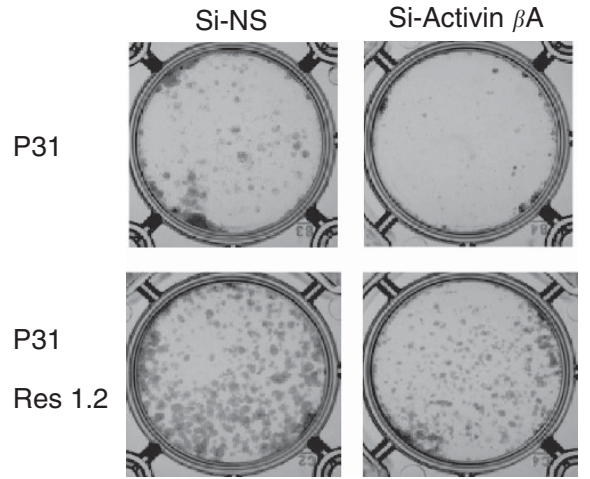

Figure 5 Silencing of activin A impairs MPM cell viability and clonogenic growth. (A) Cells were transfected with siRNA targeting activin $\beta A$ (siActivin $\beta A$ ) or with a non-silencing control siRNA (si-NS). Fourty-eight hours after transfection, RNA was extracted and reverse transcribed. Knockdown efficiency compared with the non-silencing control was determined by Taqman assays. (B) A total of $2 \times 10^{3}$ cells were seeded into 96-well plates and transfected with siRNA. Viability was determined by MTT assay $72 \mathrm{~h}$ after transfection. (C) Overall, $10^{3}$ MPM cells were seeded into 12-well plates and transfected with siRNA. After 10 days colonies were stained with crystal violet. ${ }^{*} * P<0.01$, ${ }^{*} * * P=0.001$.

associated with epitheloid histology, a histological subtype of MPM generally associated with a better outcome after trimodality treatment (Musk et al, 2011).

No previous reports have been published on the impact of activin A on MPM cell behaviour. Therefore, we tested on the one hand the effect of recombinant activin $\mathrm{A}$, and on the other hand inhibition of activin receptors. Activin A stimulated clonogenic growth and enhanced cell migration similar to the findings described for activin $\mathrm{A}$ in oesophageal adenocarcinoma and lung adenocarcinoma (Seder et al, 2009a,b). Collectively, these data suggest that in each of these thoracic malignancies activin A has a

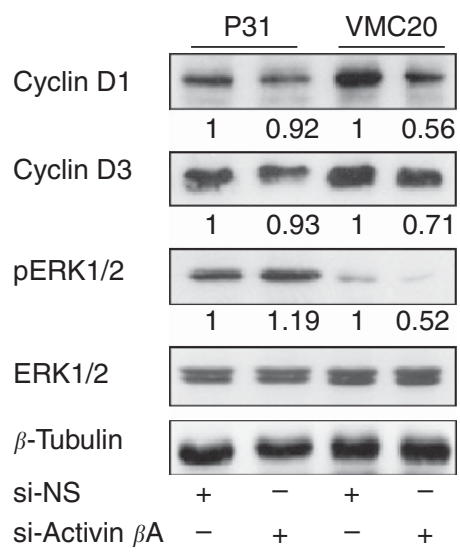

Figure 6 Silencing of activin A impairs cyclin D expression. Cells were transfected with siRNA targeting activin $\beta$ A (si-Activin $\beta A$ ) or with a nonsilencing control siRNA (si-NS). After $48 \mathrm{~h}$, protein lysates were assayed for the expression of cyclin DI, cyclin D3, pERKI/2, ERKI/2 and $\beta$-tubulin as loading control. Representative blots plus the normalised (to si-NS) band intensity ratios of cyclin DI/ $\beta$-tubulin, cyclin D3/ $\beta$-tubulin and pERK/ERK from three experiments are shown.

tumour promoting rather than a tumour-suppressive effect. In colorectal and pancreatic carcinoma it was demonstrated that the growth inhibitory effect of activin A on tumour cells is lost by mutations in type I or type II activin receptors (Su et al, 2001; Hempen et al, 2003). In our MPM cell line series the main type I receptor for activin A (ALK4) was downregulated and the type II receptor ACVR2 was upregulated. However, the canonical activin/ activin receptor/SMAD signalling axis was intact as evidenced by activin A-induced stimulation of SMAD2 phosphorylation.

Further confirming a pro-tumourigenic role of activin $\mathrm{A}$ in MPM, suppression of activin signals by two different inhibitors targeting activin receptor serine/threonine kinases led to a dosedependent decrease of clonogenicity and, moreover, significantly delayed wound closure in scratch assays, reflecting an inhibitory effect on cell migration. As the available kinase inhibitors also target the TGF- $\beta$ receptor ALK5 (Inman et al, 2002), we further confirmed our results more specifically by silencing activin expression with siRNA, which resulted in decreased viability both in short- and long-term assays.

Several reports have attributed effects of activin A to noncanonical activation of the MAPK pathway (Grusch et al, 2010) and to cell type-dependent positive (Ogawa et al, 2003) or negative (Yamato et al, 1997) regulation of cyclin D2 expression. Although stimulation with activin A for 30 min showed no indication for MAPK activation, VMC20 cells with high endogenous activin A expression and pSMAD2 levels responded to activin silencing with reduced levels of pERK, cyclin D1 and cyclin D3, which may at least in part explain the observed growth suppression. However, in contrast to a report on prostate cancer cells (Ying et al, 1997), no regulation of p53 by activin A treatment or silencing was observed in MPM cells (data not shown).

The finding that the kinase inhibitors had a greater antigrowth impact than the siRNA may implicate that also TGF- $\beta$ has a role in MPM cell growth. This is in line with previous results (Suzuki et al, 2007) and has led to the initiation of a clinical study with a monoclonal antibody targeting TGF- $\beta$ in relapsed MPM (http:// ClinicalTrials.gov Identifier: NCT01112293). Our data indicate that also activin A may represent a potential target for intervention in MPM. In this regard, kinase inhibitors co-targeting TGF- $\beta$ and activin receptors may even be of some advantage as increased efficiency of multitargeted approaches is also being discussed for tyrosine kinase inhibitors, for instance in lung cancer (Socinski, 2011). 
In summary, our investigation for the first time addresses the role of activins in MPM and suggests them as valuable candidates for further evaluation.

\section{ACKNOWLEDGEMENTS}

We thank Barbara Dekan for perfect technical assistance with the Western blots. We knowledge the Grant support by the Fund of the
City of Vienna for Innovative Interdisciplinary Cancer Research to $\mathrm{MAH}$ and by the Herzfelder Foundation to MG.

\section{Conflict of interest}

The authors declare no conflict of interest.

Supplementary Information accompanies the paper on British Journal of Cancer website (http://www.nature.com/bjc)

\section{REFERENCES}

Antsiferova M, Huber M, Meyer M, Piwko-Czuchra A, Ramadan T, Macleod AS, Havran WL, Dummer R, Hohl D, Werner S (2011) Activin enhances skin tumourigenesis and malignant progression by inducing a protumourigenic immune cell response. Nat Commun 2: 576

Burdette JE, Jeruss JS, Kurley SJ, Lee EJ, Woodruff TK (2005) Activin A mediates growth inhibition and cell cycle arrest through Smads in human breast cancer cells. Cancer Res 65: 7968-7975

Chang KP, Kao HK, Liang Y, Cheng MH, Chang YL, Liu SC, Lin YC, Ko TY, Lee YS, Tsai CL, Wang TH, Hao SP, Tsai CN (2010) Overexpression of activin A in oral squamous cell carcinoma: association with poor prognosis and tumor progression. Ann Surg Oncol 17: 1945-1956

Chen W, Woodruff TK, Mayo KE (2000) Activin A-induced HepG2 liver cell apoptosis: involvement of activin receptors and smad proteins. Endocrinology 141: 1263-1272

Fitzpatrick DR, Bielefeldt-Ohmann H, Himbeck RP, Jarnicki AG, Marzo AL, Robinson BW (1994) Transforming growth factor-beta: antisense RNAmediated inhibition affects anchorage-independent growth, tumorigenicity and tumor-infiltrating T-cells in malignant mesothelioma. Growth Factors 11: 29-44

Frost K, Seir K, Lackner A, Grusch M, Grasl-Kraupp B, Schulte-Hermann R, Rodgarkia-Dara C (2011) Inhibin/activin expression in human and rodent liver: subunits alpha and betaB as new players in human hepatocellular carcinoma? Br J Cancer 104: 1303-1312

Gold E, Jetly N, O'Bryan MK, Meachem S, Srinivasan D, Behuria S, SanchezPartida LG, Woodruff T, Hedwards S, Wang H, McDougall H, Casey V, Niranjan B, Patella S, Risbridger G (2009) Activin C antagonizes activin A in vitro and overexpression leads to pathologies in vivo. Am J Pathol 174: 184-195

Grusch M, Drucker C, Peter-Vorosmarty B, Erlach N, Lackner A, Losert A, Macheiner D, Schneider WJ, Hermann M, Groome NP, Parzefall W, Berger W, Grasl-Kraupp B, Schulte-Hermann R (2006) Deregulation of the activin/follistatin system in hepatocarcinogenesis. $J$ Hepatol 45: 673-680

Grusch M, Petz M, Metzner T, Ozturk D, Schneller D, Mikulits W (2010) The crosstalk of RAS with the TGF-beta family during carcinoma progression and its implications for targeted cancer therapy. Curr Cancer Drug Targets 10: 849-857

Hempen PM, Zhang L, Bansal RK, Iacobuzio-Donahue CA, Murphy KM, Maitra A, Vogelstein B, Whitehead RH, Markowitz SD, Willson JK, Yeo CJ, Hruban RH, Kern SE (2003) Evidence of selection for clones having genetic inactivation of the activin A type II receptor (ACVR2) gene in gastrointestinal cancers. Cancer Res 63: 994-999

Hoda MA, Mohamed A, Ghanim B, Filipits M, Hegedus B, Tamura M, Berta J, Kubista B, Dome B, Grusch M, Setinek U, Micksche M, Klepetko W, Berger W (2011) Temsirolimus inhibits malignant pleural mesothelioma growth in vitro and in vivo: synergism with chemotherapy. $J$ Thorac Oncol 6: 852-863

Inman GJ, Nicolas FJ, Callahan JF, Harling JD, Gaster LM, Reith AD, Laping NJ, Hill CS (2002) SB-431542 is a potent and specific inhibitor of transforming growth factor-beta superfamily type I activin receptorlike kinase (ALK) receptors ALK4, ALK5, and ALK7. Mol Pharmacol 62: 65-74

Jackman DM (2009) Current options for systemic therapy in mesothelioma. Semin Thorac Cardiovasc Surg 21: 154-158

Jeruss JS, Sturgis CD, Rademaker AW, Woodruff TK (2003) Downregulation of activin, activin receptors, and Smads in high-grade breast cancer. Cancer Res 63: 3783-3790

Jung B, Doctolero RT, Tajima A, Nguyen AK, Keku T, Sandler RS, Carethers JM (2004) Loss of activin receptor type 2 protein expression in microsatellite unstable colon cancers. Gastroenterology 126: 654-659

Kelly RJ, Sharon E, Hassan R (2011) Chemotherapy and targeted therapies for unresectable malignant mesothelioma. Lung Cancer 73: 256-263

Musk AW, Olsen N, Alfonso H, Reid A, Mina R, Franklin P, Sleith J, Hammond N, Threlfall T, Shilkin KB, de Klerk NH (2011) Predicting survival in malignant mesothelioma. Eur Respir J 38: 1420-1424

Ogawa T, Yogo K, Ishida N, Takeya T (2003) Synergistic effects of activin and FSH on hyperphosphorylation of $\mathrm{Rb}$ and $\mathrm{G} 1 / \mathrm{S}$ transition in rat primary granulosa cells. Mol Cell Endocrinol 210: 31-38

Peto J, Decarli A, La Vecchia C, Levi F, Negri E (1999) The European mesothelioma epidemic. Br J Cancer 79: 666-672

Razanajaona D, Joguet S, Ay AS, Treilleux I, Goddard-Leon S, Bartholin L, Rimokh R (2007) Silencing of FLRG, an antagonist of activin, inhibits human breast tumor cell growth. Cancer Res 67: 7223-7229

Risbridger GP, Schmitt JF, Robertson DM (2001) Activins and inhibins in endocrine and other tumors. Endocr Rev 22: 836-858

Robinson BW, Lake RA (2005) Advances in malignant mesothelioma. $N$ Engl J Med 353: 1591-1603

Sagmeister S, Eisenbauer M, Pirker C, Mohr T, Holzmann K, Zwickl H, Bichler C, Kandioler D, Wrba F, Mikulits W, Gerner C, Shehata M, Majdic O, Streubel B, Berger W, Micksche M, Zatloukal K, SchulteHermann R, Grasl-Kraupp B (2008) New cellular tools reveal complex epithelial-mesenchymal interactions in hepatocarcinogenesis. $\mathrm{Br} J$ Cancer 99: 151-159

Seder CW, Hartojo W, Lin L, Silvers AL, Wang Z, Thomas DG, Giordano TJ, Chen G, Chang AC, Orringer MB, Beer DG (2009a) INHBA overexpression promotes cell proliferation and may be epigenetically regulated in esophageal adenocarcinoma. J Thorac Oncol 4: 455-462

Seder CW, Hartojo W, Lin L, Silvers AL, Wang Z, Thomas DG, Giordano TJ, Chen G, Chang AC, Orringer MB, Beer DG (2009b) Upregulated INHBA expression may promote cell proliferation and is associated with poor survival in lung adenocarcinoma. Neoplasia 11: 388-396

Socinski MA (2011) Multitargeted receptor tyrosine kinase inhibition: an antiangiogenic strategy in non-small cell lung cancer. Cancer Treat Rev 37: 611-617

Stove C, Vanrobaeys F, Devreese B, Van Beeumen J, Mareel M, Bracke M (2004) Melanoma cells secrete follistatin, an antagonist of activinmediated growth inhibition. Oncogene 23: 5330-5339

Su GH, Bansal R, Murphy KM, Montgomery E, Yeo CJ, Hruban RH, Kern SE (2001) ACVR1B (ALK4, activin receptor type 1B) gene mutations in pancreatic carcinoma. Proc Natl Acad Sci USA 98: 3254-3257

Sugarbaker DJ, Garcia JP, Richards WG, Harpole Jr. DH, Healy-Baldini E, DeCamp Jr. MM, Mentzer SJ, Liptay MJ, Strauss GM, Swanson SJ (1996) Extrapleural pneumonectomy in the multimodality therapy of malignant pleural mesothelioma. Results in 120 consecutive patients. Ann Surg 224: 288-294; (discussion 294-286)

Suzuki E, Kim S, Cheung HK, Corbley MJ, Zhang X, Sun L, Shan F, Singh J, Lee WC, Albelda SM, Ling LE (2007) A novel small-molecule inhibitor of transforming growth factor beta type I receptor kinase (SM16) inhibits murine mesothelioma tumor growth in vivo and prevents tumor recurrence after surgical resection. Cancer Res 67: 2351-2359

Tanaka T, Toujima S, Umesaki N (2004) Activin A inhibits growthinhibitory signals by TGF-betal in differentiated human endometrial adenocarcinoma cells. Oncol Rep 11: 875-879

Tsuchida K, Nakatani M, Hitachi K, Uezumi A, Sunada Y, Ageta H, Inokuchi K (2009) Activin signaling as an emerging target for therapeutic interventions. Cell Commun Signal 7: 15

Vejda S, Erlach N, Peter B, Drucker C, Rossmanith W, Pohl J, SchulteHermann R, Grusch M (2003) Expression of activins C and E induces apoptosis in human and rat hepatoma cells. Carcinogenesis 24: 1801-1809 
Vogelzang NJ, Rusthoven JJ, Symanowski J, Denham C, Kaukel E, Ruffie P, Gatzemeier U, Boyer M, Emri S, Manegold C, Niyikiza C, Paoletti P (2003) Phase III study of pemetrexed in combination with cisplatin versus cisplatin alone in patients with malignant pleural mesothelioma. J Clin Oncol 21: 2636-2644

Wang Q, Wen YG, Li DP, Xia J, Zhou CZ, Yan DW, Tang HM, Peng ZH (2010) Upregulated INHBA expression is associated with poor survival in gastric cancer. Med Oncol 29(1): 77-83

Wang QF, Tilly KI, Tilly JL, Preffer F, Schneyer AL, Crowley Jr. WF, Sluss PM (1996) Activin inhibits basal and androgen-stimulated proliferation and induces apoptosis in the human prostatic cancer cell line, LNCaP. Endocrinology 137: 5476-5483

Werner S, Alzheimer C (2006) Roles of activin in tissue repair, fibrosis, and inflammatory disease. Cytokine Growth Factor Rev 17: 157-171

This work is published under the standard license to publish agreement. After 12 months the work will become freely available and the license terms will switch to a Creative Commons Attribution-NonCommercial-Share Alike 3.0 Unported License.

Yamato K, Koseki T, Ohguchi M, Kizaki M, Ikeda Y, Nishihara T (1997) Activin A induction of cell-cycle arrest involves modulation of cyclin D2 and p21CIP1/WAF1 in plasmacytic cells. Mol Endocrinol 11: 1044-1052

Ying S, Zhang Z, Batres Y, Zhao Y, Lin S, Li G (1997) p53 is involved in the inhibition of cell proliferation mediated by activin A in cultured human prostate cancer LNCaP cells. Int J Oncol 11: 591-595

Yoshinaga K, Mimori K, Yamashita K, Utsunomiya T, Inoue H, Mori M (2003) Clinical significance of the expression of activin A in esophageal carcinoma. Int J Oncol 22: 75-80

Yoshinaga K, Yamashita K, Mimori K, Tanaka F, Inoue H, Mori M (2008) Activin a causes cancer cell aggressiveness in esophageal squamous cell carcinoma cells. Ann Surg Oncol 15: 96-103

Zucali PA, Giaccone G (2006) Biology and management of malignant pleural mesothelioma. Eur J Cancer 42: 2706-2714 